\title{
HEAT STROKE: CLINICAL AND CHEMICAL OBSERVATIONS ON 44 CASES ${ }^{1,2}$
}

\author{
By EUGENE B. FERRIS, JR., M. A. BLANKENHORN, HOWARD W. ROBINSON, \\ AND GLENN E. CULLEN \\ (From the Departments of Internal Medicine and Pediatrics, College of Medicine, University \\ of Cincinnati, the Cincinnati General Hospital, and the Children's Hospital Research \\ Foundation, Cincinnati)
}

(Received for publication December 28, 1937)

The problem of heat diseases has long been an important one in the tropics, in certain industries and occupations requiring exposure of individuals to high temperatures, and during periods of excessively hot weather in the cities of the United States. In spite of the voluminous literature on the subject, there is no unanimity of opinion regarding the predisposing and precipitating factors which bring about such reactions.

Three fairly distinct clinical syndromes may occur as the result of an excessively high environmental temperature. These are heat cramps, heat exhaustion, and heat stroke. The syndrome of heat cramps has long been known among workers in hot environments. In addition to severe muscular cramps, these patients sweat profusely and have a normal temperature. The work of Edsall (1), Moss (2), Haldane (3), Glover (4), Talbott and his coworkers $(5,6)$, and others (7) suggests that this syndrome results primarily from an excessive loss of electrolytes, namely sodium chloride, in the sweat. The symptoms can be relieved or prevented by the administration of sodium chloride, and the mortality is negligible. The syndrome of heat exhaustion is characterized by profuse perspiration, pallor of the skin and low blood pressure-manifestations of peripheral circulatory collapse. The temperature may be subnormal, normal, or slightly elevated. The symptoms are of a syncopal nature, namely, weakness, dizziness, and sometimes fainting. Nausea and vomiting may occur. As a rule, heat exhaustion is not a serious condition. Recovery is rapid and the mortality low. Heat stroke, on the other hand, is a most serious condition, having a mor-

1 These studies were aided in part by a grant from the Union Central Life Insurance Company.

2 Presented in abstract form at the May 1937 meeting of the American Society for Clinical Investigation, Atlantic City, New Jersey. tality which ranges from 10 to 80 per cent $(8,9)$. The syndrome is characterized by an extremely high body temperature and profound coma. Sun stroke, heat collapse, thermal fever, and heat hyperpyrexia are terms used to describe this condition, the most outstanding feature of which is a high body temperature. Heat stroke may be preceded by symptoms of heat exhaustion or it may develop suddenly, without warning to the victim. It is probably the cause of the majority of deaths attributed primarily to excessively hot weather.

Various observers differ regarding the relative importance of the various factors which, in addition to the high environmental temperature, may be responsible for the breakdown in the heat regulatory mechanism in heat stroke. Many observers $(2,3,10,11,12,13,14)$, have stressed the importance of a high humidity. Sayers and Davenport (10) and Adolph and Fulton (11) studied its effect by producing moderate elevations of body temperature in humans in a hot, humid environment. Alcoholism $(8,10,12,13)$ and old age $(10,13,15)$ have been demonstrated to be important contributory factors in the development of heat stroke. Metropolitan Life Insurance statistics show that 75 per cent of the deaths resulting from heat stroke occur in patients over 60 years of age (16). Since the chief means of heat dissipation are radiation, conduction and convection, and evaporation from the skin, various explanations involving the breakdown of these mechanisms have been proposed as the primary cause for heat stroke. Circulatory failure $(11,17,18,19)$, acidosis (20), "fatigue" of the sweat glands (21), the influence of the sun on the heat regulatory center $(22,23)$, and increased body metabolism (15) have each been held responsible for the breakdown in the heat 
regulatory mechanism and for the clinical manifestations.

There is also a difference of opinion in the literature concerning certain of the clinical manifestations, such as the state of the peripheral circulation, cardiac function and function of the sweat glands, which might bear on the pathogenesis as well as therapy in this condition. A number of observers have stressed peripheral circulatory failure or congestive heart failure as important clinical manifestations of heat stroke $(13,14,22,24,28)$, giving the impression that pulmonary edema, cardiac failure, and shock are common. In a series of 64 cases reported by Gauss and Meyer (8) failure of the circulation was not a prominent feature. While several observers $(7,8,13,21,22,23)$, report that sweating is typically absent in heat stroke, others (9, $13,24)$, state that sweating may occur.

During two severe heat waves in the summer of 1936, 44 patients suffering from heat stroke were admitted to the Medical Service of the Cincinnati General Hospital. We think that the results of our studies on these patients should clarify certain conflicting ideas regarding the pathogenesis, clinical manifestations, and treatment of heat stroke.

\section{METHOD OF STUDY}

Only those patients in whom a definite diagnosis of heat stroke (hyperpyrexia) could be made were selected for this study. The diagnosis was not difficult in those having rectal temperatures above $106^{\circ} \mathrm{F}$. For 9 patients who had admission temperatures ranging from 104 to $106^{\circ}$ the diagnosis depended upon the elimination of other possible causes of an elevated temperature, and upon the subsequent course.

Because the majority of the patients were admitted over a very short period of time, our facilities were greatly overtaxed and complete studies could not be made on all. However, 39 patients who lived long enough to be examined were given routine physical examinations, and blood was taken for routine red blood cell count, hemoglobin determination, white blood cell count, differential smear, and blood Kahn before treatment was instituted. The clinical course of all patients was followed as closely as possible. Rectal temperatures were recorded in all cases. The thermometers used were calibrated only to $110^{\circ} \mathrm{F}$., but it was possible to approximate closely temperatures up to $112^{\circ} \mathrm{F}$. on some of them.

In a selected group of patients, clinical and blood chemical studies were carried out on admission and re- peated immediately following the reduction in temperature by ice water baths but before any other therapy was instituted. Control studies on those patients who survived were made just previous to discharge and at least 2 days following any parenteral administration of fluid or salt. In addition to a routine examination, particular attention was paid to the arterial blood pressure, respiration, pulse, skin color, mental state, lung signs, presence or absence of edema, and venous blood pressure of each patient in this group. Blood samples were obtained under oil from the femoral artery and femoral vein and were used for as many of the following determinations as possible: nonprotein nitrogen, total protein, A/G ratio, sodium chloride, sodium, potassium, cholesterol, hemoglobin, hematocrit, red blood cell count, carbon dioxide content, and oxygen content. The chloride concentration of the initial specimen of urine was determined in 2 patients. The clotting time of venous blood obtained at the time of admission was determined in 5 cases. The pressure in the femoral vein was obtained by the direct method of Moritz and Tabora (25) in 12 cases. Clotting time was determined simultaneously by the tube and capillary methods.

Chlorides were determined by the method of Van Slyke (26). Oxygen and carbon dioxide contents of the oxalated blood, taken with the precautions outlined by Austin, Cullen, Hastings, McLean, Peters, and Van Slyke (27), were made by the gasometric methods described by Peters and Van Slyke (28), employing the Van Slyke-Neill manometric apparatus. The oxygen capacity values were calculated, using the factor of $1.34 \mathrm{cc}$. per gram of hemoglobin, from hemoglobin determinations that were obtained by the colorimetric carbon monoxide method of Palmer (29). A Wratten filter, Number 74, was employed with the Duboscq colorimeter. The percentage of red blood cell volume was determined by the method of Guest and Siler (30). The serum protein values are based on nitrogen determinations by the microKjeldahl method. In the fractionation of the serum protein, the Howe method (31) with the precipitation of the globulin by 22 per cent sodium sulfate solution was used. The details of the micro-Kjeldahl apparatus, digestion, and distillation are described by Robinson, Price and $\mathrm{Cul}$ len (32). Serum sodium was determined by the uranyl zinc acetate method of Butler and Tuthill (33), and serum potassium by the method of Shohl and Bennett (34).

Because of the temporary confusion which resulted from the sudden appearance of so many critically ill patients on the medical wards, a standard routine of treatment could not be immediately formulated. Therefore, an opportunity to observe the effects of several recognized forms of treatment was presented. The 9 patients whose rectal temperatures were $106^{\circ} \mathrm{F}$. or below were either treated initially with cold sheets and fans or were given no specific temperature-lowering treatment. Since these patients were conscious and rational and were able to take fluids by mouth, a container of water having 4 grams of sodium chloride per quart was placed at their bedsides for them to drink as desired. Two of the 
severely ill patients ${ }^{3}$ also were treated with cold sheets and fans. This procedure consisted in wrapping the patients in cold wet sheets and facilitating evaporation by blowing air over the sheets and at the same time massaging the skin through the sheets. Twenty-five of the severely ill patients were immersed to the neck in a tub full of ice water and the skin was rubbed vigorously until the temperature was approximately 100 to $102^{\circ}$ $\mathrm{F}$. Following the reduction in temperature, 23 of this severely ill group were given physiological saline parenterally in amounts ranging from 2000 to $4000 \mathrm{cc}$. daily until they either died or recovered sufficiently to take fluids by mouth. The remaining 2 patients of this group of 25 were given no fluids until they recovered sufficiently to take them by mouth.

One patient was administered $1500 \mathrm{cc}$. of physiological saline intravenously before physical measures calculated to lower the temperature were instituted. One patient was subjected to a venesection of $500 \mathrm{cc}$. One severely ill patient was given no specific treatment because he improved before cooling measures could be used. Five patients died before any therapy could be instituted.

A history was obtained from the patients who recovered and from the family and friends of all patients. In addition to the character and duration of symptoms leading up to the heat stroke, they were questioned particularly regarding habits, environment, occupation, physical exertion, exposure to sun, other diseases, and degree of sweating before the onset. In addition, a social service worker from the City Health Department inspected the home and environment of most of the cases.

\section{RESULTS}

Environmental and weather conditions. The official temperatures which were recorded during the July 1936 heat wave are listed in Table I. These were obtained by the United States Weather Bureau at the Clifton Station. The severity of this heat wave is indicated by the fact that for a period of 8 consecutive days the maximum temperature ranged from 102 to $106^{\circ} \mathrm{F}$. A less severe heat wave of 4 days' duration occurred in August, but since 42 of the 44 patients included in this study were stricken during the July heat wave we shall limit the description of weather conditions to this period. We have no exact knowledge of the temperature of the environment in which the individual patients lived, but it is certain that their actual environment was considerably hotter than the official temperature

3 All patients having rectal temperatures above $106^{\circ} \mathrm{F}$. were considered to be severely ill, since the majority of these were comatose. Thirty-five patients were classed as having severe and nine as having mild heat stroke.
TABLE I

Official weather reports obtained from the Clifton Weather Observatory during the July 1936 heat wave

\begin{tabular}{|c|c|c|c|c|c|c|c|c|c|c|}
\hline \multirow{2}{*}{$\begin{array}{c}\text { Date } \\
\text { July }\end{array}$} & \multicolumn{5}{|c|}{ Official temperature } & \multicolumn{3}{|c|}{$\begin{array}{l}\text { Relative } \\
\text { humidity }\end{array}$} & \multirow{2}{*}{$\underset{\text { fall }}{\text { Rain- }}$} & \multirow{2}{*}{$\begin{array}{l}\text { Num- } \\
\text { ber of } \\
\text { pa- } \\
\text { tients } \\
\text { ad- } \\
\text { mitted }\end{array}$} \\
\hline & $\begin{array}{l}\text { Maxi- } \\
\text { mum }\end{array}$ & $\underset{\text { mum }}{\text { Mini- }}$ & Mean & $\begin{array}{c}8 \\
\text { p.m. }\end{array}$ & $\begin{array}{l}\text { Mid- } \\
\text { night }\end{array}$ & $\begin{array}{c}8 \\
\text { a.m. }\end{array}$ & Noon & $\begin{array}{c}8 \\
\text { p.m. }\end{array}$ & & \\
\hline $\begin{array}{r}8 \\
9 \\
10 \\
11 \\
12 \\
13 \\
14 \\
15 \\
16 \\
17\end{array}$ & $\begin{array}{c}\bullet F . \\
103 \\
103 \\
105 \\
104 \\
105 \\
102 \\
106 \\
104 \\
91 \\
98\end{array}$ & $\begin{array}{l}\bullet P . \\
70 \\
75 \\
78 \\
72 \\
74 \\
79 \\
75 \\
78 \\
74 \\
71\end{array}$ & $\begin{array}{l}{ }^{\circ} P . \\
86 \\
89 \\
92 \\
88 \\
90 \\
90 \\
80 \\
91 \\
82 \\
84\end{array}$ & $\begin{array}{l}{ }^{\circ} P . \\
90 \\
94 \\
93 \\
80^{*} \\
96 \\
96 \\
96 \\
82 \\
85 \\
92\end{array}$ & $\begin{array}{l}\circ P . \\
83 \\
85 \\
81 \\
79 \\
88 \\
85 \\
89 \\
78 \\
81 \\
81\end{array}$ & $\begin{array}{l}\text { per } \\
\text { cent } \\
68 \\
70 \\
59 \\
77 \\
68 \\
62 \\
64 \\
58 \\
80 \\
58\end{array}$ & $\begin{array}{c}\text { per } \\
\text { cent } \\
31 \\
36 \\
26 \\
41 \\
36 \\
31 \\
28 \\
35 \\
66 \\
16\end{array}$ & $\begin{array}{c}\text { per } \\
\text { cent } \\
48 \\
45 \\
44 \\
63 \\
38 \\
32 \\
35 \\
55 \\
66 \\
22\end{array}$ & $\begin{array}{l}\text { inches } \\
0 \\
0 \\
0 \\
0.65 \\
0 \\
0 \\
0 \\
0 \\
0 \\
0\end{array}$ & $\begin{array}{r}0 \\
0 \\
4 \\
0 \\
5 \\
7 \\
9 \\
14 \\
2 \\
1\end{array}$ \\
\hline $\begin{array}{c}\text { Average } \\
\text { July } 8 \\
\text { to } 15\end{array}$ & 104 & 75 & 89.2 & $94^{*}$ & $85^{*}$ & 65.3 & 33 & 45 & & \\
\hline $\begin{array}{l}\text { Average fo } \\
\text { month } \\
\text { exclusive } \\
\text { July } 8 \\
\text { to } 15\end{array}$ & 89.4 & 68.5 & 79 & 79.5 & 75 & 72.2 & 45.4 & 49 & & \\
\hline
\end{tabular}

* With rainfall, the temperature fell from $104^{\circ}$ at 4 p.m. to $80^{\circ}$ at 5 p.m. on July 11 . The night temperature averages do not include temperatures on this date or on the evening of July 15 when the heat wave subsided.

at the Clifton Station which is situated on one of the hills which surround the more thickly populated "basin" section of Cincinnati. The Bureau also maintains a station on top of the government building approximately 75 feet above street level in downtown Cincinnati, which is situated on low, level ground along the Ohio River basin. This region includes the business and crowded tenement districts of the city. The average mean temperature during the period under discussion was $2^{\circ} \mathrm{F}$. higher in the downtown district. The daily maximum temperature was identical at the two stations but the night temperature was considerably higher in the "basin."

An investigation of the homes of patients who developed heat stroke indicate that the majority lived under conditions which favored an excessively warm environment, namely, the majority lived on top floors of brick buildings covered with flat roofs. ${ }^{4}$ It is of interest that 91 per cent of the patients resided in densely settled regions of the city.

The relative humidity as determined 3 times daily by the Weather Bureau in Clifton is listed

$4 \mathrm{We}$ are indebted to Dr. F. Kirby Harder, Acting Commissioner of Health of Cincinnati, for investigating the homes of heat stroke victims. 
in Table I. The average humidity, as one would expect, was considerably less during the heat wave than the average for the remainder of the month.

Direct exposure to the rays of the sun did not appear to be an important factor, as only 10 patients had been exposed for a significant period of time. Likewise, physical exertion appeared of little importance. Only 9 patients were doing work which at most required moderate exercise at the time of or preceding their collapse. Thirteen of the patients were employed and working during the heat wave, but none was engaged in occupations which required exposure to an environment any warmer than that encountered by the average person.

The daily number of admissions of patients suffering from heat stroke is tabulated in Table I. There were no admissions until the third day of the heat wave, and thereafter, with the exception of July 11, the daily admissions rose progressively for the duration of the heat wave. The lack of admissions on July 11 was probably owing to the fact that coincidently with a rainstorm in the early afternoon the temperature fell rapidly and remained near $80^{\circ} \mathrm{F}$. for the remainder of the day and night. It is significant that most of the patients entered the hospital in the afternoon or evening.

Other predisposing factors. The age of the patients varied from 25 to 90 years. However, only 7 of them were less than 50 years of age. This distribution of ages is shown in Figure 1. It is evident that the greatest frequency of age distribution is in the period of 60 to 70 years.

Alcoholic beverages appeared to play a significant rôle in the development of heat stroke in a number of patients. We were able to get reliable information concerning the drinking habits of 38 patients. Of these, 17 (44 per cent) had consumed significant amounts of beer or whiskey on the day of their collapse and in many cases for several preceding days. However, only 2 of these patients were considered to be chronic drinkers and none showed definite evidence of deficiency disease. Seven additional patients had consumed amounts of alcohol insufficient to be considered significant. Fourteen patients, chiefly women, denied consumption of alcohol.

As the age of the patients would indicate, the

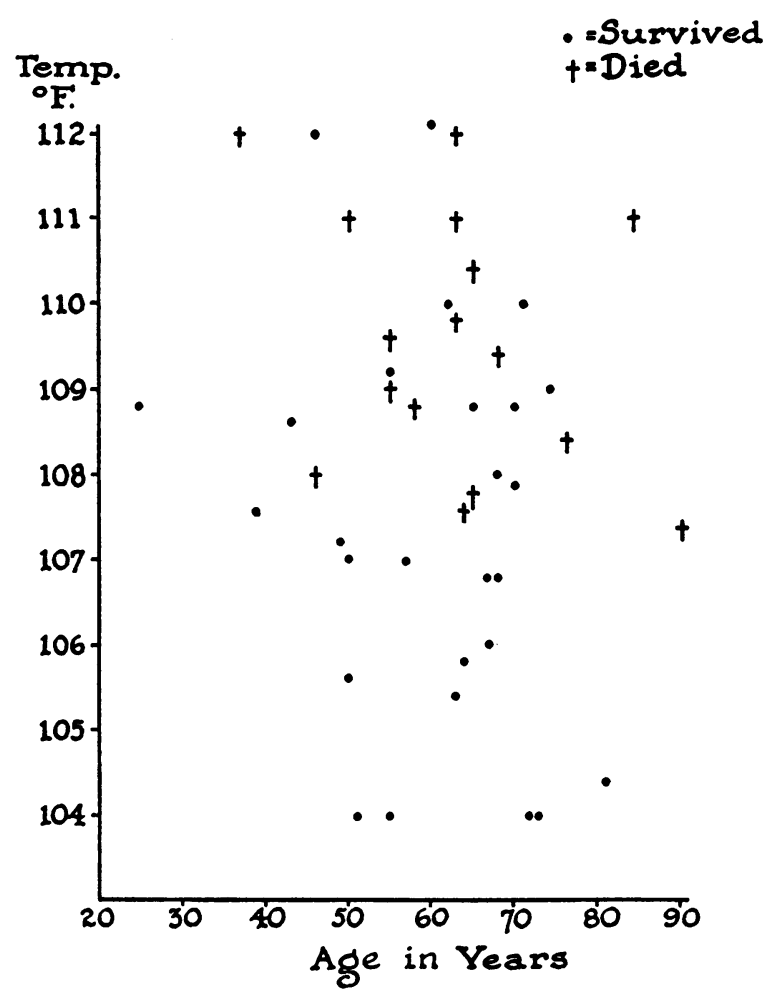

Fig. 1. A Composite Chart Indicating the Age, Admission Temperature, and OUtcome in 44 CASEs of Heat Stroke.

Most of the patients were over 50 years of age. None of the patients having temperatures below $107^{\circ} \mathrm{F}$. died. In the patients having temperatures above $107^{\circ} \mathrm{F}$., there is no clear relationship between temperature and mortality or between age and mortality.

majority presented clinical evidence of degenerative vascular disease. Eight gave a history of symptoms suggesting early congestive failure; of these, 2 had auricular fibrillation and 2 gave a history suggestive of coronary artery disease. Benign arterial hypertension was present in 10 patients. Two suffered from degenerative disease of the brain. Of the 3 patients who were less than 40 years of age, 2 were alcoholic addicts, and the other suffered from an acute respiratory infection, postpartum anemia, and malnutrition. This relationship between heat stroke and disease has been noted previously (35). The sex incidence was of no significance; 27 were males and 17 females. The racial incidence may be significant ; 37 were white and 7 colored, a ratio of 5 to 1 , whereas the ratio of white to colored patients admitted to the hospital from the densely 
populated regions of the city during the summer of 1936 was roughly 3 to 2 .

Prodromal symptoms. An adequate history of symptoms preceding the onset of heat stroke was obtained from 24 patients. Fourteen patients suddenly collapsed and lost consciousness. Of the 14 patients, 5 had suffered from weakness, dizziness, nausea, and occasional attacks of fainting over a period of 2 to 3 days preceding their collapse; 5 had noticed slight headache or weakness and a feeling of excessive heat; and 6 had had no premonitory symptoms whatsoever. The onset was gradual in the 9 patients who suffered from mild heat stroke and was accompanied by a feeling of excessive heat. The onset was gradual in only 2 of the patients who were affected severely. A history of typical muscle cramps was obtained from only 1 patient; however, a number had suffered from attacks of abdominal pain previous to the onset of the stroke.

An attempt was made to ascertain from the histories whether or not these patients had noted any abnormality in their sweating habits during the period of hot weather preceding their illness and also near the time of onset of their symptoms. In 21 patients who could give information on the subject, sweating did not appear to be significantly altered during the hot weather previous to the onset of their illness. Five thought that they had sweat excessively, 3 less than usual, and 13 had perspired normally under the circumstances. However, a significant number noted cessation of sweat just previous to the onset of heat stroke. Seventeen patients noted and volunteered the information that they ceased sweating at this time. None of the patients gave a history of excessive sweating at the onset.

\section{Clinical manifestations}

Observations during the acute attack. The more important clinical manifestations which were observed in this study are tabulated in Table II. Since the syndrome of heat stroke has been frequently described $(8,12,20,21)$, we shall limit this report largely to those manifestations which we believe to have a bearing on the mechanism of this condition or about which there is some confusion.

The most outstanding findings in this group of patients were an abnormally high body tempera- ture, coma, and a dry skin. Depending on the body temperature, these patients could be divided into 2 distinct groups. Nine of the patients had temperatures of $106^{\circ} \mathrm{F}$. or less. These patients were conscious and did not appear to be extremely ill. The remaining 35 patients had temperatures ranging from 106.8 to $112^{\circ} \mathrm{F}$., were either unconscious or stuporous, and were classified as being severely ill. The distribution of the temperatures is shown graphically in Figure 1.

The absence of sweat was a finding common to all 44 patients and was the most characteristic feature. The skin was very hot, dry, and flushed. In 23 patients a characteristic maculopapular skin rash was present over the body, being most marked over the chest, abdomen, and back. This eruption was fiery red in color and in many areas was purpuric. On admission most of the more severely affected patients who were in coma showed other evidence of a depressed nervous system; the muscles were flaccid, respirations were rapid and deep, tendon reflexes were diminished, and the patients were incontinent of feces. The 9 patients less severely affected presented no abnormal neurological findings except that several were mentally confused. Respirations were increased in rate and depth but were not labored.

Because both cardiac and peripheral circulatory failure have been described as characteristic features of heat stroke and also have been held responsible for this condition, we shall describe in more detail the changes which were observed in the cardiovascular system. These findings are listed in Tables II and III. In no instance was there evidence of definite congestive failure, as peripheral edema, venous engorgement, and orthopnea were absent. The more severely affected patients showed evidence of increased bronchial secretion in that large bronchial and tracheal râles could be heard. However, parenchymal basal râles were present to a significant degree in only 7 patients, most of whom had a previous history of mild congestive failure. Pulmonary edema was evident in only 1 obviously moribund patient. The absence of a significant degree of congestive failure was further evident in those patients studied more extensively (Table III) in whom venous pressure and arterial oxygen saturation were relatively normal. Furthermore, it is significant that with the exception of basal râles, 
TABLE II

Initial clinical observations on 44 patients with heat stroke and their subsequent course

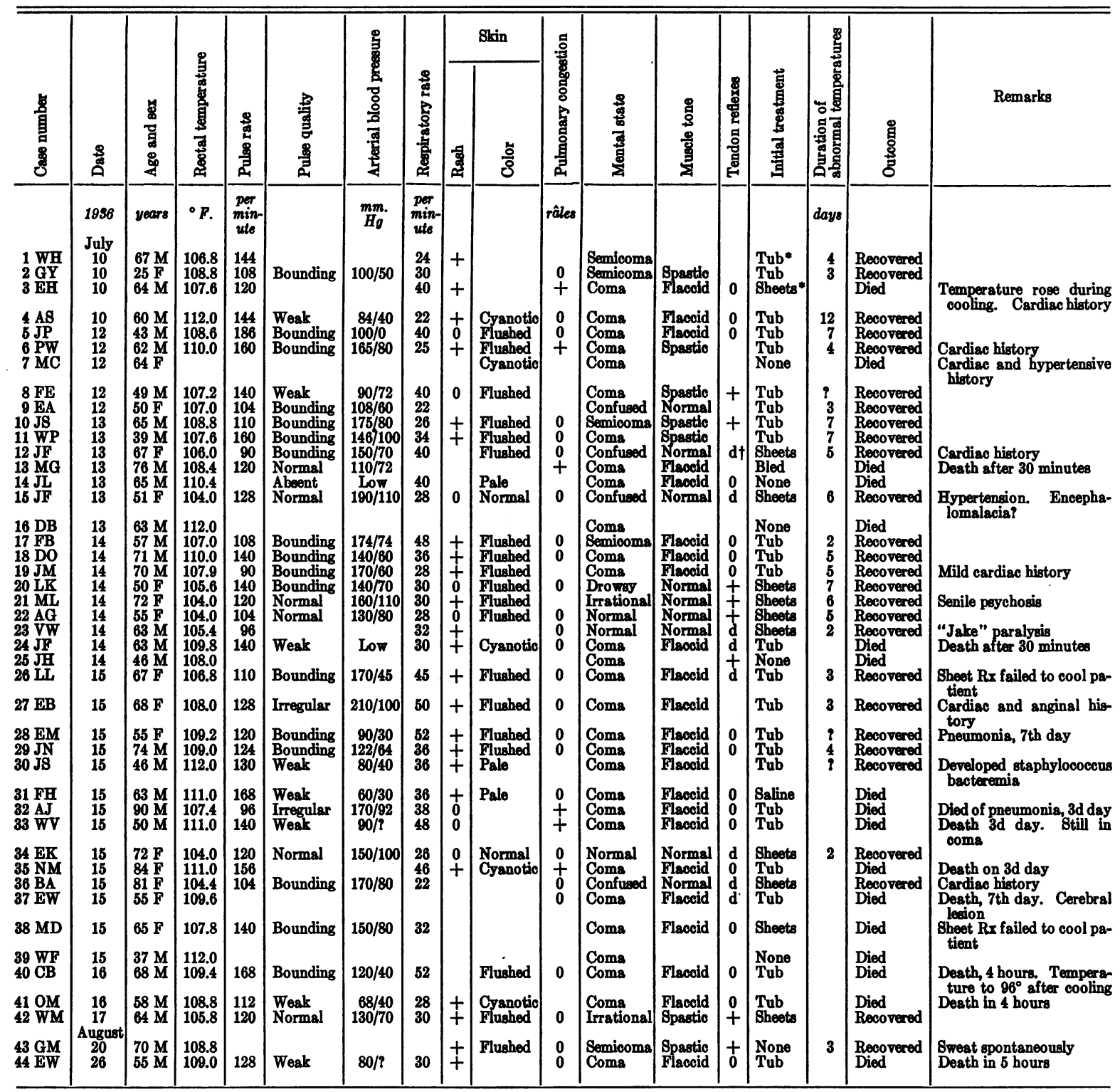

* Tub treatment indicates that the patients were immersed in a tub of ice water and vigorously massaged. Sheet treatment indicates that the patients were covered with dripping wet sheets on which were directed several electric fans; at the same time, the skin was massaged through the sheet.

$\dagger \mathrm{d}$ indicates depressed tendon reflexes.

other signs of congestive failure were not present in the 8 patients who presented historical evidence of poor cardiac function. All 8 of these patients had previously suffered from dyspnea on exertion and 2 from peripheral edema.

The state of the peripheral vascular system in these patients is indicated by the data listed in
Tables II and III. Shock as evidenced by a low blood pressure and feeble pulse was present in only 7 of the 34 patients whose blood pressures were obtained on admission. These 7 patients appeared to be in extremis. In the remainder, the radial pulse was full, the pulse pressure wide, and the systolic blood pressure usually elevated. 
TABLE III

Clinical and chemical observations on 19 patients during several stages of heat stroke $\ddagger$

\begin{tabular}{|c|c|c|c|c|c|c|c|c|c|c|c|c|c|c|c|c|c|c|c|c|c|c|}
\hline \multicolumn{11}{|c|}{ Clinical obeervations } & \multicolumn{12}{|c|}{ Blood chemical findir gs } \\
\hline \multirow[b]{2}{*}{ ठ } & \multirow[b]{2}{*}{ 昜 } & \multirow[b]{2}{*}{ 目 } & \multirow{2}{*}{ 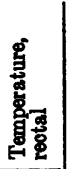 } & \multirow{2}{*}{$\begin{array}{l}\text { 量 } \\
\text { 量 } \\
\text { 量 }\end{array}$} & \multirow{2}{*}{ 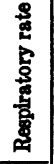 } & \multirow{2}{*}{ 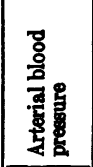 } & \multirow{2}{*}{ 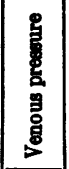 } & \multirow{2}{*}{ 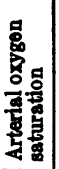 } & \multirow{2}{*}{ 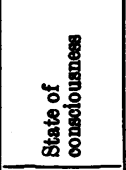 } & \multirow{2}{*}{ 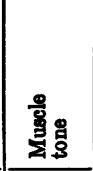 } & \multirow{2}{*}{ 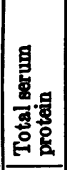 } & \multirow{2}{*}{ 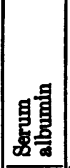 } & \multirow{2}{*}{ 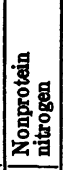 } & \multirow{2}{*}{ 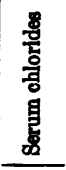 } & \multirow{2}{*}{$\begin{array}{l}\text { 睆 } \\
8 \\
\text { 慁 } \\
\text { 蛊 }\end{array}$} & \multicolumn{2}{|c|}{$\begin{array}{l}\text { Femoral } \\
\text { arterial }\end{array}$} & \multicolumn{2}{|c|}{$\begin{array}{l}\text { Femoral } \\
\text { venous }\end{array}$} & \multirow{2}{*}{$\begin{array}{l}\text { 量 } \\
\text { 융 } \\
\text { 貣 }\end{array}$} & \multirow{2}{*}{ 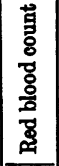 } & \multirow{2}{*}{ 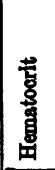 } \\
\hline & & & & & & & & & & & & & & & & 8 & ర요용 & 总㝵 & ర용 & & & \\
\hline J. $\stackrel{\mathbf{5}}{\mathbf{P} .}$ & $\begin{array}{c}1956 \\
\text { July } \\
12 \\
20\end{array}$ & $\begin{array}{l}\text { 7:45 p.m. } \\
\text { 8:15 p.m. }\end{array}$ & $\begin{array}{r}108.6 \\
101.4 \\
98.8 \\
\end{array}$ & $\begin{array}{c}\text { per } \\
\text { min- } \\
\text { ute } \\
\\
186 \\
140 \\
85\end{array}$ & $\begin{array}{c}\text { per } \\
\text { min- } \\
\text { ute }\end{array}$ & $\begin{array}{l}\operatorname{mm} . H_{g} \\
\\
100 / 0 \\
110 / 58\end{array}$ & $\stackrel{\mathrm{cm}}{\mathrm{H}_{2} \mathrm{O}}$ & $\begin{array}{l}\text { per } \\
\text { cent }\end{array}$ & $\begin{array}{l}\text { Coma } \\
\text { Semicoma } \\
\text { Normal }\end{array}$ & $\begin{array}{l}\text { Flaceld } \\
\text { Spastic } \\
\text { Normal }\end{array}$ & $\begin{array}{c}\text { grams } \\
\text { per } \\
100 \\
\propto c . \\
\\
7.2 \\
8.1 \\
7.2\end{array}$ & $\begin{array}{c}\text { grams } \\
\text { per } \\
100 \\
\text { cc. } \\
\\
4.4 \\
5.6 \\
5.0\end{array}$ & $\begin{array}{c}\text { mom. } \\
\text { per } \\
100 \\
\propto \\
\\
\\
37 \\
38 \\
29\end{array}$ & \begin{tabular}{|r} 
m.eq. \\
pert \\
liter \\
\\
\\
95.6 \\
94.0 \\
108.2 \\
\end{tabular} & $\begin{array}{l}\text { m.eq. } \\
\text { per } \\
\text { liter }\end{array}$ & $\begin{array}{c}\text { vol } \\
\text { umes } \\
\text { per } \\
\text { cent }\end{array}$ & $\begin{array}{c}\text { vol } \\
\text { umes } \\
\text { per } \\
\text { cent }\end{array}$ & $\begin{array}{c}\text { wot } \\
\text { umes } \\
\text { per } \\
\text { cent }\end{array}$ & $\begin{array}{c}\text { vol } \\
\text { umes } \\
\text { per } \\
\text { cent }\end{array} \mid$ & $\begin{array}{c}\text { grams } \\
\text { per } \\
100 \\
c c . \\
\\
12.8 \\
15.0\end{array}$ & $\begin{array}{c}\text { mil } \\
\text { lions } \\
\text { per } \\
\text { cu. } \\
\text { mm. }\end{array}$ & $\begin{array}{l}\text { not } \\
\text { umes } \\
\text { per } \\
\text { cont }\end{array}$ \\
\hline P. $\stackrel{6}{W}$. & 12 & 8:00 p.m. & 110.0 & 160 & 25 & $165 / 80$ & & & Semicoma & Spastio & 8.0 & 6.1 & 32 & 23.8 & & & & & & 12.6 & & \\
\hline F. $\stackrel{8}{\mathrm{E} .}$ & 12 & 7:20 p.m. & 107.2 & 140 & 40 & $90 / 72$ & & & Coma & Flscoid & 8.3 & 5.7 & 35 & 103.5 & & & & & & 12.6 & & \\
\hline $\begin{array}{r}10 \\
\text { J. S. }\end{array}$ & $\begin{array}{l}13 \\
14 \\
16\end{array}$ & $\begin{array}{l}\text { 3:15 p.m. } \\
\text { 3:52 p.m. }\end{array}$ & \begin{tabular}{r|}
108.8 \\
100.0 \\
100.0 \\
98.8
\end{tabular} & \begin{tabular}{r|}
110 \\
96 \\
68
\end{tabular} & $\begin{array}{l}26 \\
20 \\
18\end{array}$ & $\begin{array}{l}175 / 80 \\
135 / 80 \\
130 / 80 \\
120 / 80\end{array}$ & $\begin{array}{l}9.5 \\
9.0 \\
5.0 \\
5.5\end{array}$ & $\begin{array}{l}91.1 \\
94.0 \\
92.5 \\
90.2\end{array}$ & $\begin{array}{l}\text { Coms } \\
\text { Confused } \\
\text { Normal } \\
\text { Normal }\end{array}$ & $\begin{array}{l}\text { Flaccid } \\
\text { Spastic } \\
\text { Normal } \\
\text { Normal }\end{array}$ & $\begin{array}{l}7.9 \\
7.9 \\
6.7 \\
6.8\end{array}$ & $\begin{array}{l}5.0 \\
4.8 \\
4.2 \\
4.3\end{array}$ & $\begin{array}{l}28 \\
30 \\
22 \\
24\end{array}$ & \begin{tabular}{r|}
98.9 \\
98.7 \\
100.2 \\
101.5
\end{tabular} & $\begin{array}{l}138.0 \\
136.0 \\
133.5 \\
141.2\end{array}$ & \begin{tabular}{|l|}
17.7 \\
18.4 \\
16.5 \\
16.8
\end{tabular} & \begin{tabular}{l|}
32.3 \\
33.5 \\
44.4 \\
48.9
\end{tabular} & \begin{tabular}{r|}
7.2 \\
13.8 \\
10.4 \\
10.5
\end{tabular} & $\begin{array}{l}37.8 \\
37.2 \\
46.0 \\
54.4\end{array}$ & $\begin{array}{l}14.5 \\
14.6 \\
13.3 \\
13.9\end{array}$ & $\begin{array}{l}4.28 \\
4.42 \\
3.81 \\
4.05\end{array}$ & $\begin{array}{l}43.9 \\
45.0 \\
41.2 \\
42.4\end{array}$ \\
\hline $\begin{array}{l}11 \\
\text { W. P. }\end{array}$ & $\begin{array}{l}13 \\
14 \\
18 \\
\end{array}$ & $\begin{array}{l}\text { 7:15 p.m. } \\
\text { 7:45 p.m. }\end{array}$ & $\begin{array}{r}107.6 \\
101.5 \\
100.2 \\
98.6 \\
\end{array}$ & $\begin{array}{r}160 \\
136 \\
92 \\
80 \\
\end{array}$ & $\begin{array}{l}34 \\
22 \\
20\end{array}$ & \begin{tabular}{|l|}
$146 / 100$ \\
$115 / 72$ \\
$130 / 88$ \\
$112 / 72$ \\
\end{tabular} & $\begin{array}{r}10.5 \\
12.0^{*} \\
9.0 \\
8.0\end{array}$ & \begin{tabular}{|l|}
86.8 \\
93.2 \\
95.3
\end{tabular} & $\begin{array}{l}\text { Coma } \\
\text { Semicoma } \\
\text { Normal } \\
\text { Normal }\end{array}$ & \begin{tabular}{l|} 
Flaccid \\
Spastic \\
Normal \\
Normal
\end{tabular} & $\begin{array}{l}6.5 \\
7.7 \\
6.1 \\
6.7 \\
\end{array}$ & $\begin{array}{l}4.4 \\
5.3 \\
4.1 \\
4.3 \\
\end{array}$ & $\begin{array}{l}30 \\
34 \\
26 \\
23\end{array}$ & \begin{tabular}{|l|}
111.9 \\
106.4 \\
106.4 \\
102.5 \\
\end{tabular} & $\begin{array}{l}140.0 \\
134.4 \\
\end{array}$ & \begin{tabular}{|l|}
17.1 \\
15.8 \\
17.0 \\
\end{tabular} & $\begin{array}{l}28.3 \\
25.5 \\
40.0 \\
41.3 \\
\end{array}$ & $\begin{array}{r}11.5 \\
96 . \\
12.2 \\
10.5 \\
\end{array}$ & $\begin{array}{l}32.8 \\
28.7 \\
42.4 \\
46.4 \\
\end{array}$ & $\begin{array}{l}14.7 \\
15.7 \\
12.5 \\
13.3 \\
\end{array}$ & $\begin{array}{l}5.16 \\
5.16 \\
4.40 \\
4.82 \\
\end{array}$ & $\begin{array}{l}47.2 \\
48.8 \\
39.9 \\
42.9 \\
\end{array}$ \\
\hline $\begin{array}{r}17 \\
\text { F. B. }\end{array}$ & $\begin{array}{l}14 \\
18\end{array}$ & $\begin{array}{l}\text { 6:15 p.m. } \\
\text { 6:40 p.m. }\end{array}$ & $\begin{array}{r}107.0 \\
101.5 \\
99.0 \\
\end{array}$ & $\begin{array}{r}108 \\
88 \\
60 \\
\end{array}$ & $\begin{array}{l}48 \\
32 \\
20 \\
\end{array}$ & $\begin{array}{l}174 / 74 \\
130 / 80 \\
150 / 82 \\
\end{array}$ & $\begin{array}{r}10.0 \\
10.0 \\
8.5 \\
\end{array}$ & \begin{tabular}{l|}
89.4 \\
91.2 \\
95.5 \\
\end{tabular} & $\begin{array}{l}\text { Coma } \\
\text { Irrational } \\
\text { Normal }\end{array}$ & $\begin{array}{l}\text { Flacoid } \\
\text { Spastic } \\
\text { Normal } \\
\end{array}$ & $\begin{array}{l}7.3 \\
6.4 \\
\end{array}$ & $\begin{array}{l}4.7 \\
4.0 \\
\end{array}$ & $\begin{array}{l}33 \\
21 \\
\end{array}$ & $\begin{array}{l}103.8 \\
101.5 \\
\end{array}$ & & \begin{tabular}{l|}
16.9 \\
17.6 \\
17.8 \\
\end{tabular} & $\begin{array}{l}39.3 \\
41.0 \\
50.8 \\
\end{array}$ & $\begin{array}{l}13.0 \\
12.3 \\
14.7 \\
\end{array}$ & \begin{tabular}{l|}
42.3 \\
44.9 \\
55.0 \\
\end{tabular} & $\begin{array}{l}14.1 \\
14.4 \\
13.9 \\
\end{array}$ & $\begin{array}{r}5.30 \\
5.32 \\
\end{array}$ & $\begin{array}{l}44.8 \\
43.8 \\
\end{array}$ \\
\hline $\begin{array}{l}18 \\
\text { D. } 0 .\end{array}$ & $\begin{array}{l}14 \\
20 \\
\end{array}$ & $\begin{array}{l}\text { 3:08 p.m. } \\
\text { 3:40 p.m. }\end{array}$ & $\begin{array}{r}110.0 \\
101.8 \\
99.0 \\
\end{array}$ & $\begin{array}{r}140 \\
100 \\
74 \\
\end{array}$ & $\begin{array}{l}50 \\
32 \\
20 \\
\end{array}$ & $\begin{array}{l}140 / 60 \\
150 / 90\end{array}$ & $\begin{array}{l}4.0 \\
6.0\end{array}$ & \begin{tabular}{l|}
88.3 \\
98.6 \\
95.0 \\
\end{tabular} & $\begin{array}{l}\text { Coms } \\
\text { Irrational } \\
\text { Normal }\end{array}$ & $\begin{array}{l}\text { Flaccid } \\
\text { Spastic } \\
\text { Normal }\end{array}$ & $\begin{array}{l}7.3 \\
7.8 \\
6.1 \\
\end{array}$ & & $\begin{array}{l}\mathbf{5 6} \\
\mathbf{5 7} \\
\mathbf{3 1} \\
\end{array}$ & $\begin{array}{r}99.1 \\
101.1 \\
104.4 \\
\end{array}$ & & \begin{tabular}{l|}
17.9 \\
18.9 \\
16.3 \\
\end{tabular} & \begin{tabular}{l|}
31.1 \\
26.5 \\
47.8 \\
\end{tabular} & \begin{tabular}{r|}
10.6 \\
7.4 \\
5.6 \\
\end{tabular} & \begin{tabular}{|l|}
36.6 \\
32.1 \\
56.5 \\
\end{tabular} & \begin{tabular}{|l|}
13.6 \\
14.3 \\
12.8 \\
\end{tabular} & $\begin{array}{l}4.26 \\
4.62\end{array}$ & $\begin{array}{l}42.0 \\
44.6\end{array}$ \\
\hline J. $\stackrel{19}{\mathrm{M}}$ & $\begin{array}{l}14 \\
22 \\
\end{array}$ & $\begin{array}{l}\text { 7:30 p.m. } \\
\text { 8:25 p.m. }\end{array}$ & $\begin{array}{r}107.9 \\
99.0 \\
98.0 \\
\end{array}$ & $\begin{array}{r}90 \\
100 \\
74 \\
\end{array}$ & $\begin{array}{l}28 \\
22 \\
18 \\
\end{array}$ & $\begin{array}{l}170 / 60 \\
185 / 100\end{array}$ & $\begin{array}{r}11.5 \\
16.0^{*} \\
5.0\end{array}$ & & $\begin{array}{l}\text { Coma } \\
\text { Irrational } \\
\text { Normal }\end{array}$ & $\begin{array}{l}\text { Flacoid } \\
\text { Spastic } \\
\text { Normal }\end{array}$ & $\begin{array}{l}6.6 \\
6.6 \\
\end{array}$ & $\begin{array}{l}4.3 \\
4.2\end{array}$ & $\begin{array}{l}37 \\
42\end{array}$ & $\begin{array}{r}103.8 \\
97.2 \\
\end{array}$ & & $\begin{array}{l}13.5 \\
16.5 \\
\end{array}$ & \begin{tabular}{l|}
38.3 \\
51.8 \\
\end{tabular} & \begin{tabular}{r|}
10.4 \\
7.9 \\
10.5 \\
\end{tabular} & \begin{tabular}{l|}
43.4 \\
44.3 \\
56.8 \\
\end{tabular} & \begin{tabular}{l|}
12.3 \\
12.9 \\
13.9 \\
\end{tabular} & 4.33 & $\overline{38.0}$ \\
\hline L. $\mathbf{K}$. & $\begin{array}{l}14 \\
18 \\
\end{array}$ & 4:15 p.m. & $\begin{array}{r}105.6 \\
99.0 \\
\end{array}$ & $\begin{array}{r}140 \\
72 \\
\end{array}$ & $\begin{array}{l}30 \\
20 \\
\end{array}$ & $\begin{array}{l}140 / 70 \\
112 / 70\end{array}$ & $\begin{array}{l}8.0 \\
6.0 \\
\end{array}$ & & $\begin{array}{l}\text { Drowsy } \\
\text { Normal }\end{array}$ & $\begin{array}{l}\text { Normal } \\
\text { Normal }\end{array}$ & $\begin{array}{l}6.4 \\
6.7 \\
\end{array}$ & & $\begin{array}{l}36 \\
29 \\
\end{array}$ & $\begin{array}{l}108.0 \\
101.9 \\
\end{array}$ & & & & $\begin{array}{l}12.0 \\
12.6\end{array} \mid$ & \begin{tabular}{|l|}
48.8 \\
51.7
\end{tabular} & $\begin{array}{l}12.1 \\
13.9 \\
\end{array}$ & $\begin{array}{l}3.52 \\
4.56 \\
\end{array}$ & $\begin{array}{l}36.8 \\
43.3 \\
\end{array}$ \\
\hline $\begin{array}{r}26 \\
\text { L. } \mathbf{L} .\end{array}$ & $\begin{array}{l}15 \\
22 \\
\end{array}$ & 1:00 p.m. & $\begin{array}{r}106.8 \\
99.0 \\
\end{array}$ & $\begin{array}{r}110 \\
72 \\
\end{array}$ & $\begin{array}{l}45 \\
20 \\
\end{array}$ & $\begin{array}{l}170 / 45 \\
190 / 74\end{array}$ & & & $\begin{array}{l}\text { Coms } \\
\text { Normal }\end{array}$ & $\begin{array}{l}\text { Flaccid } \\
\text { Normal }\end{array}$ & $\begin{array}{l}8.7 \\
6.6\end{array}$ & & $\begin{array}{l}54 \\
24 \\
\end{array}$ & $\begin{array}{l}83.4 \\
97.8 \\
\end{array}$ & \begin{tabular}{l|}
139.6 \\
149.6 \\
\end{tabular} & & & & & 13.9 & 4.75 & 45.8 \\
\hline E. B. & $\begin{array}{l}15 \\
16 \\
22\end{array}$ & $\begin{array}{l}\text { 1:35 p.m. } \\
\text { 2:25 p.m. }\end{array}$ & \begin{tabular}{r|}
108.9 \\
101.8 \\
99.0 \\
99.0 \\
\end{tabular} & $\begin{array}{r}128 \\
78 \\
76 \\
76 \\
\end{array}$ & $\begin{array}{l}50 \\
26 \\
20 \\
20 \\
\end{array}$ & $\begin{array}{l}210 / 100 \\
154 / 102 \\
146 / 100 \\
160 / 100 \\
\end{array}$ & & & $\begin{array}{l}\text { Coms } \\
\text { Semicoms } \\
\text { Irrationsl } \\
\text { Normal } \\
\end{array}$ & $\begin{array}{l}\text { Flaceid } \\
\text { Spastic } \\
\text { Normal } \\
\text { Normal } \\
\end{array}$ & $\begin{array}{l}9.2 \\
6.1 \\
\end{array}$ & & $\begin{array}{l}42 \\
25 \\
\end{array}$ & $\begin{array}{l}115.4 \\
100.9 \\
\end{array}$ & $\begin{array}{l}162.2 \\
140.4 \\
\end{array}$ & & & & & & & \\
\hline E. $\stackrel{28}{\mathbf{M}}$. & $\begin{array}{l}15 \\
22 \\
\end{array}$ & $\begin{array}{l}\text { 3:10 p.m. } \\
\text { 4:45 p.m. }\end{array}$ & \begin{tabular}{r|}
109.0 \\
99.2 \\
99.0 \\
\end{tabular} & $\begin{array}{r}120 \\
104 \\
72 \\
\end{array}$ & $\begin{array}{l}36 \\
24 \\
20 \\
\end{array}$ & $\begin{array}{r}90 / 30 \\
130 / 70 \\
140 / 88 \\
\end{array}$ & & & $\begin{array}{l}\text { Coms } \\
\text { Coma } \\
\text { Normal }\end{array}$ & $\begin{array}{l}\text { Flaccid } \\
\text { Normal }\end{array}$ & $\begin{array}{l}8.0 \\
6.4 \\
\end{array}$ & & $\begin{array}{l}39 \\
23 \\
\end{array}$ & $\begin{array}{l}114.0 \\
108.9 \\
\end{array}$ & $\begin{array}{l}146.6 \\
155.0 \\
\end{array}$ & & & & & 14.1 & 4.78 & 43.5 \\
\hline J. $\stackrel{29}{N}$. & $\begin{array}{l}15 \\
22\end{array}$ & $\begin{array}{l}\text { 4:50 p.m. } \\
\text { 5:30 p.m. }\end{array}$ & $\begin{array}{r}109.0 \\
102.0 \\
99.0 \\
\end{array}$ & $\begin{array}{r}140 \\
104 \\
80 \\
\end{array}$ & $\begin{array}{l}34 \\
28 \\
20 \\
\end{array}$ & $\begin{array}{l}122 / 64 \\
108 / 68 \\
130 / 90\end{array}$ & $\begin{array}{c}10.0 \\
16.0^{\circ} \\
5.5 \\
\end{array}$ & \begin{tabular}{|l|}
90.7 \\
93.5
\end{tabular} & $\begin{array}{l}\text { Coms } \\
\text { Semicoms } \\
\text { Normsl } \\
\end{array}$ & $\begin{array}{l}\text { Flacoid } \\
\text { Spastic } \\
\text { Normal } \\
\end{array}$ & $\begin{array}{l}7.9 \\
6.5 \\
\end{array}$ & & $\begin{array}{l}30 \\
20 \\
\end{array}$ & $\begin{array}{r}95.8 \\
100.7 \\
\end{array}$ & $\begin{array}{l}130.3 \\
137.5\end{array}$ & $\begin{array}{l}17.5 \\
19.8 \\
16.1\end{array}$ & \begin{tabular}{|l|}
33.8 \\
26.1 \\
48.8
\end{tabular} & $\begin{array}{r}9.4 \\
9.5 \\
13.0\end{array}$ & $\begin{array}{l}40.2 \\
35.1 \\
52.2\end{array}$ & \begin{tabular}{|l|}
14.4 \\
15.8 \\
13.7
\end{tabular} & 4.89 & 44.8 \\
\hline $\begin{array}{r}30 \\
\text { J. S. }\end{array}$ & $\begin{array}{l}15 \\
17 \\
\end{array}$ & 3:00 p.m. & $\begin{array}{l}112.0 \\
101.0\end{array}$ & $\begin{array}{r}130 \\
88\end{array}$ & $\begin{array}{l}36 \\
22 \\
\end{array}$ & $\begin{array}{r}80 / 40 \\
130 / 80\end{array}$ & & & $\begin{array}{l}\text { Coms } \\
\text { Confused }\end{array}$ & $\begin{array}{l}\text { Flaccid } \\
\text { Normal }\end{array}$ & $\begin{array}{l}8.0 \\
6.4\end{array}$ & & $\begin{array}{l}\mathbf{3 6} \\
\mathbf{3 7} \\
\end{array}$ & $\begin{array}{r}104.2 \\
96.2 \\
\end{array}$ & & & & & & 12.1 & 3.99 & 37.1 \\
\hline F. $\stackrel{31}{\mathrm{H}}$. & 15 & 3:00 p.m. & 111.0 & 168 & 36 & $60 / 30$ & 4.0 & & $\overline{\text { Coma (died) }}$ & Flaccid & 7.8 & & 37 & 96.8 & & & & 12.0 & 22.8 & 14.3 & 4.30 & 43.5 \\
\hline $\begin{array}{r}32 \\
\text { A. J. }\end{array}$ & $\begin{array}{l}15 \\
17\end{array}$ & $\begin{array}{l}\text { 8:30 a.m. } \\
\text { 9:15 a.m. }\end{array}$ & \begin{tabular}{|l|}
107.4 \\
101.6 \\
101.0 \\
\end{tabular} & $\begin{array}{r}100 \\
96 \\
120 \\
\end{array}$ & $\begin{array}{l}38 \\
28 \\
42 \\
\end{array}$ & $\begin{array}{l}170 / 92 \\
190 / 110\end{array}$ & $\begin{array}{l}6.5 \\
6.0\end{array}$ & 23.5 & $\begin{array}{l}\text { Coms } \\
\text { Coms } \\
\text { Coms (died) }\end{array}$ & $\begin{array}{l}\text { Flaccid } \\
\text { Spastic } \\
\text { Flaccid } \\
\end{array}$ & 7.6 & 4.2 & 41 & 95.6 & 135.7 & 17.9 & 37.8 & 9.5 & 45.8 & 14.3 & 4.82 & 42.3 \\
\hline $\begin{array}{c}33 \\
w \cdot v .\end{array}$ & $\begin{array}{l}15 \\
17 \\
\end{array}$ & $\begin{array}{l}\text { 3:30 p.m. } \\
\text { 4:05 p.m. }\end{array}$ & $\begin{array}{r}111.0 \\
99.0 \\
100.4 \\
\end{array}$ & $\begin{array}{l}140 \\
140 \\
100 \\
\end{array}$ & $\begin{array}{l}48 \\
36 \\
16 \\
\end{array}$ & $\begin{array}{c}90 / ? \\
132 / 70 \\
128 / 80\end{array}$ & & & $\begin{array}{l}\text { Coma } \\
\text { Coma } \\
\text { Coma (died) }\end{array}$ & $\begin{array}{l}\text { Flaccid } \\
\text { Spastic } \\
\text { Flaccid }\end{array}$ & 8.4 & & 47 & 107.0 & & & & & & 14.3 & 5.08 & 45.8 \\
\hline G. M.t & \begin{tabular}{|c|} 
Aug. \\
20 \\
22 \\
\end{tabular} & $\begin{array}{l}\text { 8:00 p.m. } \\
\text { 8:30 p.m. }\end{array}$ & \begin{tabular}{r|}
108.4 \\
105.6 \\
98.6 \\
\end{tabular} & $\begin{array}{r}104 \\
76 \\
\end{array}$ & $\begin{array}{l}48 \\
18\end{array}$ & $170 / 78$ & & & $\begin{array}{l}\text { Coms } \\
\text { Confused } \\
\text { Normal }\end{array}$ & $\begin{array}{l}\text { Flaccid } \\
\text { Spastic } \\
\text { Normal }\end{array}$ & & & & $\begin{array}{r}90.0 \\
101.0 \\
\end{array}$ & & & & & & & & $\begin{array}{l}44.3 \\
42.0 \\
\end{array}$ \\
\hline F. W. & 26 & 3:15 p.m. & 109.0 & 128 & 36 & $80 / 0$ & & & Coms (died) & Flaceid & & & & 91.0 & & & & & & & & 41.3 \\
\hline
\end{tabular}

* Struggled during venous pressure determination.

† Patient's skin was dry on admission but he sweated spontaneously, and improved before any treatment was instituted.

$\ddagger$ Successive observations on the same day indicate initial observations and those taken immediately following temperature lowering procedures but before administration of fluids or electrolytes. The final observations on patients who survived were made at least two days after parenteral fluids had been discontinued. 
The venous pressure of 12 of the more severely ill patients ranged from 2.0 to $12 \mathrm{~cm}$. saline, in most instances being at the upper limits of normal. The skin was hot and hyperemic. The difference in oxygen content between the femoral arterial and venous blood ranged from 3.1 to 10.5 volumes per cent in 6 patients, the average being 6.4 . These figures do not indicate a great retardation in peripheral blood flow when one considers the greatly increased tissue metabolism which must be present with such a high body temperature. In the absence of congestive failure, the presence of a rapid full pulse, high pulse pressure, hyperemic skin without cyanosis, and a high normal venous pressure in the majority of patients suggests that in most instances the peripheral blood flow rather than being decreased was actually considerably faster than normal.

Observations following reduction in body temperature. Twenty-five of the more severely affected patients were immersed in ice water immediately after admission, thereby causing a rapid reduction in the body temperature and a dramatic change in the clinical appearance as the falling temperature reached 107 to $106^{\circ} \mathrm{F}$. At this point the patients, who were previously flaccid and unconscious, became rigid and struggled so violently that considerable effort was necessary to prevent their escaping from the tub or injuring themselves. Several of the patients regained consciousness at this point and many others muttered incoherently. Goose-flesh appeared over the skin. The patients were removed from the tub when their temperatures had reached 102.5 to $99^{\circ} \mathrm{F}$. The observations noted at this time are listed in Table III. There was a striking decrease in the respiratory rate and pulse rate. The blood pressure approached a more normal level in most instances, namely, the pulse pressure became less and the systolic pressure fell. The blood pressure also approached normal in several of the patients in whom it had previously been low. The majority of the severely ill patients remained delirious and required restraint for from 4 to 12 hours after being cooled. One patient subsequently developed delirium tremens and 2 patients remained in coma until death supervened. The temperature remained unstable for from 3 to 12 days, ranging from 97 to $103^{\circ}$ F., and was usually elevated. The majority of the patients did not sweat until several days after admission. In 2 patients sweating was observed to occur simultaneously with the return of the temperature to normal.

\section{The chemistry of the blood}

Blood concentration. In Table III are tabulated values for protein, hemoglobin, and cell volume percentage. In most instances the serum protein and hematocrit values were greater than the control values of samples obtained after clinical recovery and indicate that hemoconcentration was present (Table III). The degree of blood concentration was much less than that reported by Talbott et al. (6) in patients with severe heat cramps who, in contrast with our patients, were conscious and had normal body temperature. It is of interest that in 7 instances blood samples taken from patients immediately after therapeutic reduction in temperature showed evidence of greater concentration than on admission, in spite of the fact that the patient's condition had improved greatly.

In 8 cases albumin was determined, and in all 8 there was no evidence of the high globulin, low albumin ratio reported for heat cramps. Moreover, the high level of albumin in those patients with the high total protein level is much greater evidence for a concentrated blood owing to loss of fluid than is the total protein level alone.

Sodium and chloride concentration in the serum. In Table III are included the values for chloride level in serum from 18 patients and for sodium in 7 patients. It is at once evident that the chloride level on admission varies to both sides of the normal values of 98 to $108 \mathrm{~m}$. eq. per liter (557 to $632 \mathrm{mgm}$. per cent sodium chloride). In only 1 case (Case 26) was the chloride at the extremely low level found by Talbott and others in severe heat cramps and in only 3 other cases was the chloride level below the round figure of $96 \mathrm{~m}$. eq. In 3 patients the chlorides were much above the normal level. Of these, the high values in Cases 27 and 28 were possibly due to concentration of blood serum as evidenced by the high protein level. There is no evidence of such concentration in Case 11, which is unusual in that the chloride level on admission was high without elevation either of albumin or total protein, although there was evidence of a concentration of 
hemoglobin. After the initial tubbing, although it is evident from the protein and hemoglobin values that there was a concentration of blood and serum, the chloride fell.

In the 1 case (Case 26) in which the chloride was already extremely low, both the chloride and sodium concentration rose during the half-hour of tubbing.

The sodium values ran fairly parallel with the chlorides. Potassium was determined in only two cases: Case 10, 3:52 p.m. $=3.8 \mathrm{~m}$. eq., and Case 32, 8:30 a.m. $=2.2 \mathrm{~m}$. eq.

All these values, taken together, make it appear to us that the situation with regard to the electrolytes in this type of heat stroke is entirely different from that of heat cramps, and that in the present case the changes in electrolytes are coincidental rather than causative.

The acid-base balance. The total carbon dioxide content of both femoral arterial and venous blood was definitely low, although in no case was the alkali reserve lowered sufficiently to account for the coma. Immediately after the initial tubbing and reduction of body temperature, in 5 cases there was little change in carbon dioxide content, in 3 there was a further definite decrease of 4 to 5 volumes per cent carbon dioxide in spite of marked clinical improvement. (Note that these values are for whole blood, which is always lower than serum.) Two patients in whom an increased blood concentration occurred coincidentally with cooling likewise developed a more severe acidosis. Since the reduction in body temperature was accompanied by considerable muscular exercise incident to struggling, the increased oxygen debt and lactic acid accumulation caused thereby may account for this lowering.

Unfortunately, determinations of $\mathrm{pH}$ and lactic acid were not obtained in this study, but analysis of the data furnished a fairly clear picture of the acid-base condition. There is no consistent shift of chloride in relation to serum protein, blood carbon dioxide content, or total sodium which would indicate an important alteration in the total electrolyte balance. The variations in total carbon dioxide content are well outside the possible changes that might be a result of the alteration in blood temperature (35) or to overventilation. We conclude, therefore, that the acidosis is due to the accumulation of non-volatile meta- bolic acids, probably lactic, and that it is secondary to the high body temperature. This interpretation is in agreement with the work of Hall and Wakefield (36), who produced hyperpyrexia in dogs and found a great increase in the lactic acid and reduction of the $\mathrm{pH}$ of the blood.

Oxygen content. The oxygen content of the arterial blood in 7 patients at the time of admission ranged from 13.5 to 17.9 volumes per cent and averaged 16.9 volumes per cent. The average arterial oxygen content of blood obtained from the same patients at the time of discharge was 16.7 volumes per cent. The oxygen content of blood obtained from the femoral vein varied from 7.2 to 13.0 volumes per cent. The arteriovenous oxygen difference varied greatly, as Table III indicates. Because the tissue metabolism is probably greatly increased in this condition and is probably subject to great changes under the conditions of these studies, the $\mathrm{A}-\mathrm{V}$ oxygen difference can not be used to estimate the relative blood flow in the leg. It is of interest, however, that the arterial oxygen content was approximately normal in these patients.

Other blood findings. The clotting time was normal in $\mathbf{5}$ of the severely affected patients whose skin rash was purpuric in nature. No increased tendency to bleed from skin puncture wounds was noted.

Urine chloride concentration. The concentrations of urinary chloride in admission specimens were 35 and $45 \mathrm{~m}$. eq. for Cases 43 and 44 . These values are low but not as low as those found by Talbott in heat cramps.

\section{Treatment}

Cold sheets and fans. The use of cold sheets and fans to facilitate evaporation and thus to lower the body temperature has been advocated by many writers $(13,20,24,37)$. Ten patients were treated by this method. Of these patients, 8 were classified as mild cases in that they were conscious and had temperatures below $105^{\circ} \mathrm{F}$.; and as a result of this treatment the temperature of each gradually fell and the 8 patients recovered. The result of this form of treatment in Cases 3 and 37 , who were in coma and had greatly elevated temperatures, was not satisfactory in that the procedure failed to lower the body temperature and both patients died. 
Ice water tubbing. Twenty-five patients, all classified as severely ill, were subjected to this form of treatment. The body temperature was reduced to below $102^{\circ} \mathrm{F}$. in from 9 to $40 \mathrm{~min}$ utes. The method proved to be very effective in lowering the body temperature rapidly and was not associated with any untoward effects except in 1 patient, whose temperature fell to $99^{\circ} \mathrm{F}$. before he was removed from the tub. The temperature of this patient subsequently fell to $96^{\circ}$ F. and he developed circulatory collapse. Although hot blankets effectually elevated the temperature, the patient subsequently died. Quite possibly such excessive cooling contributed to his death.

Of the 25 patients treated in this manner 8 died, a mortality rate of 32 per cent, which seems low considering the fact that all 25 patients were severely ill.

General measures. After adequate reduction in body temperature, the patients were watched carefully for unusual changes in body temperature; and ice packs, wet sheets with fans, or hot water bottles were applied until the temperature became stabilized.

Fluids averaging a total of $4000 \mathrm{cc}$. per day and sodium chloride averaging 16 grams per day were given by mouth to those patients who were sufficiently rational to drink and by the subcutaneous and intravenous routes to the others. Fluids and salt were withheld from 2 of the more severely ill patients until they were able to take them by mouth, a period of approximately 6 hours. The administration of fluids and salt had no obvious influence on the course of these patients' illnesses. The 2 from whom fluids were withheld recovered, and their clinical course was no different from that of the other patients. One extremely ill patient (Case 31 ) was given 2000 cc. of cold physiological saline intravenously as initial treatment. This procedure did not lower the body temperature after 30 minutes, and the patient subsequently died. One patient was subjected to a venesection and promptly died.

Mortality. Of the 44 patients admitted to the hospital 17, or 39 per cent, died. Of the 39 patients who lived long enough to obtain some form of treatment 12 , or 30 per cent, died. The prognosis appeared to be good in those patients who were conscious and had temperatures below $107^{\circ} \mathrm{F}$., since none of these died.

Pathological findings. Postmortem examinations were performed on 12 patients. The findings were of interest chiefly in that the majority of patients showed evidence of degenerative vascular disease. Bronchopneumonia was thought to have caused death in 2 cases. The others appeared to have died of heat stroke, as no anatomical cause for death could be found. The postmortem studies added no information to the pathology of heat stroke other than that already described (38).

\section{DISCUSSION}

The primary cause of the breakdown in the heat regulatory mechanism during exposure to high environmental temperatures has long been a controversial subject. The various mechanisms which the body has for dissipation of heat are well known. The mechanisms which dissipate the major portion of heat are first, radiation, conduction, and convection from the skin; and second, evaporation from the skin and, to some extent, through expired air. The first mechanism plays a major rôle in heat dissipation under normal conditions of body heat production when the environmental temperature is below that of the body. The second mechanism becomes the most important factor under the environmental conditions of this study where the atmospheric temperature approached or exceeded that of the body. Under such conditions as those found during the heat waves of 1936, it is obvious that little heat can be dissipated by means of radiation and that the major portion must be lost through the process of evaporation. That the body can tolerate extremely high environmental temperatures for a short period of time is borne out by investigation of conditions in various occupations such as those of steel workers (39) and stokers (40). It is important that such workers live in a considerably cooler environment in between such daily exposures, when presumably the body has a chance to compensate for the temporary overactivity of its heat dissipation mechanisms. Under such extreme conditions heat cramps may be prevalent unless measures are taken to replace the chlorides and water lost in the sweat. 
Our findings suggest that the cumulative effect of prolonged exposure to high temperatures is the important factor in the etiology of heat stroke in our patients. The patients did not develop heat stroke until the third day of the heat wave, and with the exception of 1 day the incidence of daily admissions rose steadily until the heat wave was over. This latent period has been repeatedly mentioned in the literature. As indicated in Table I, the apparent reason for the lack of admissions on this one day was a sudden drop in temperature which accompanied a rainstorm. On the other days the official temperature remained very high, not only throughout the day but also through most of the night. The fact that the official mean temperature was $2^{\circ} \mathrm{F}$. higher in the downtown section of the city than in the outlying Clifton district may be related to the observation that 91 per cent of our patients resided in densely settled regions. Furthermore, considering their environment, it is reasonable to assume that the majority of the patients studied were exposed to considerably greater temperatures throughout the night than the official report would indicate. The relatively low humidity present with these heat waves when the wet bulb temperature never exceeded $76^{\circ} \mathrm{F}$., and also the lack of excessive sweating and of premonitory symptoms, such as occurs in experiments carried out in atmospheres of high humidity, are facts which suggest that humidity did not play an important rôle in the production of heat stroke in these patients. Therefore, as far as the weather is concerned, the most important factor in this study was the exposure of patients to excessively high temperatures over a prolonged period.

Our results indicate a definite relationship between a sudden alteration in the sweating mechanism and high or unstable body temperature. In most instances cessation of sweat occurred acutely just preceding the actual heat stroke. Since most of the patients collapsed during periods when the environmental temperature exceeded that of the body, it is to be expected that the body temperature should have risen when sweating ceased. The observation that on admission none of the patients showed evidence of sweating and that the temperature of several patients remained unstable until sweating returned corroborates the history with regard to the im- portance of sweating. The exact mechanism which brought about the sudden cessation of sweating in these patients is not clear. It has been suggested that the sweat glands become fatigued because of overwork or because of dehydration or low body chloride. According to the history of these patients, they had perspired no more than usual during the days preceding their collapse, and as a group they had lost little or no excess of fluids or chlorides by other ways. Although blood studies indicated the presence of moderate dehydration, it was of much less extent than that seen in other conditions, such as heat cramps where sweating is profuse but in which there is no alteration in temperature. Likewise, the relatively normal blood chlorides which we found to be present did not indicate excessive loss through the sweat, nor was the degree of sweating or the clinical course strikingly influenced in these patients by the administration of sodium chloride or fluids.

Failure of the circulation has also been held to be a precipitating factor in the breakdown of heat regulation. In those patients whose collapse was preceded by symptoms of heat exhaustion, such as dizziness, weakness and fainting attacks, it might be argued that a deficient peripheral circulation did exist while blood was pooled in the periphery. However, an appreciable number of patients had no premonitory symptoms whatsoever; and, of more importance, the usual case of heat stroke showed no evidence of circulatory or of definite cardiac failure even when there was a preexisting history of cardiac symptoms and objective evidence of organic heart disease. Thus, although it is quite reasonable to assume that a high body temperature may be brought about through the failure of a deficient peripheral circulation to bring heat to the surface-and such has been shown to occur to a slight degree in cardiac failure (41)-the suddenness of onset and the lack of evidence of deficient circulation in our patients precludes this mechanism as being an important factor.

Besides environmental conditions, the most outstanding predisposing causes for the development of heat stroke in this group of patients were old age and the degenerative diseases which commonly accompany senility. Since the majority of these patients were not engaged in activities which 
would increase their body heat production, and since there is evidence that such elderly patients have a decreased tissue metabolism rather than an increased one, it is probable that excessive heat production is not a factor, but that their mechanism for heat dissipation is less effective than that of more normal individuals and can not compensate for as long a time when the person is exposed to a high environmental temperature.

The only other predisposing factor of great importance was the association of the ingestion of alcoholic beverages with the onset of heat stroke. Inasmuch as many of these patients were not chronic alcoholic addicts and gave no history of poor diet, and since the onset of heat stroke was closely related in time to the ingestion of alcohol, it seems probable that the heat stroke in such patients was precipitated by the effect of alcohol itself rather than by such secondary factors as malnutrition and vitamin deficiency, which are frequently associated with chronic alcoholism. Alcohol is known to depress vasomotor reflexes $(42,43)$, and to produce dilatation of the peripheral vessels $(39,43,44,45)$, thus increasing the loss of heat from the body and resulting in a fall in body temperature. The fall in body temperature has occurred, however, under conditions where the environmental temperature was lower than that of the body. Conversely, in an environmental temperature higher than the body, these same effects would serve rather to promote absorption of heat and thus add to the burden of dissipating heat through evaporation. This reasoning is borne out by the work of Barbour and Bourne (45) who showed that ether, which acts similarily to alcohol, causes dogs to become poikilothermic. It has also been shown that alcohol stimulates the sweating mechanism through its central action (46). Whether or not such an added stimulus to an already overworked sweating mechanism might be in part responsible for its failure remains to be demonstrated.

Our observations suggest that the clinical findings and chemical changes in the blood are the result of rather than the cause of the high body temperature. The dramatic improvement in many patients following the reduction of temperature without other treatment and without coincident change in the blood chemistry, suggests that the coma is related closely to the high tem- perature. Likewise, the respiratory rate decreased markedly without change in the carbon dioxide content of the blood, again suggesting that the increased respirations are due in part to high temperature and not altogether to acidosis. The moderate degree of blood concentration likewise did not appear to be an important factor in the symptomatology or etiology of the condition, as much more marked dehydration and blood concentration may occur without any of the symptoms of heat stroke. The sodium and chloride level of the blood in these patients was not significantly altered and these findings, together with the lack of evidence of excessive chloride loss previously, the presence of chloride in the urine, and the lack of effect of chloride administration on the clinical course, all serve to eliminate low sodium chloride concentration as an important factor in heat stroke. Normal blood chlorides in heat stroke have also been reported recently by Heilman and Montgomery (47).

Our observations are in agreement with those of most observers that in heat stroke the most important therapeutic measure is to lower the body temperature promptly and to maintain it at an approximately normal figure. In those patients who are conscious and have temperatures below $106^{\circ} \mathrm{F}$., the temperature may be lowered best by mild measures, such as wet sheets and fans or ice packs. In the severely affected patients, however, such measures did not lower the temperature effectively in our hands, and immersion of the patients in ice water was the most efficient method. Vigorous massage of the skin is of importance in any type of hydrotherapy. Since the patients are moderately dehydrated, administration of fluids is indicated but is of secondary importance. We found no indication for the routine use of cardiac and circulatory "stimulants."

Since certain theoretical objections have been raised in regard to the form of hydrotherapy which should be used in this condition, the subject deserves further comment. Water sprays to the body and fans to facilitate evaporation have been advocated as being preferable to immersion in ice water because evaporation of a gram of water will remove 590 calories, while the melting of a gram of ice will remove only 80 calories, and further, that immersion of the body in ice water is 
not only a shocking procedure but also will diminish the blood flow to the skin $(13,20,37)$. The argument that evaporation of water on the skin is more efficient in removing heat than immersion in ice water does not agree with our clinical results nor is it tenable on theoretical grounds when an abundance of ice is available. Furthermore, the immersion in ice water of patients having body temperatures above $106^{\circ} \mathrm{F}$. did not produce shock nor did we observe any pallor of the skin or other signs which indicated a decrease in blood flow to the skin.

In conclusion it may be well to define what we consider the syndrome of heat stroke to be. It is our feeling that moderate elevation of the body temperature as the result of exposure to heat is in itself not sufficient evidence on which to make the diagnosis of heat stroke. The elevation in body temperature must be accompanied by evidence of a deranged heat regulatory mechanism such as the absence or diminution of sweat, failure of the body temperature to approach a normal level promptly when the patient is removed to a cooler environment, and subsequent instability of the body temperature. This derangement of the heat regulatory mechanism is usually brought about as the result of exposure of an especially susceptible group of individuals to a high environmental temperature for several days. The high body temperature, which usually develops in dramatic fashion, is the chief cause of the typical clinical manifestations. Profound abnormalities of the peripheral circulation or of the acid base or water balance, although rarely encountered in our patients, might well occur in patients with heat stroke who, as a result of exposure to a hot moist atmosphere, had sweat profusely, or in whom vomiting or diarrhea had been a prominent feature. Our studies suggest also that similar abnormalities may result if the period of hyperpyrexia is prolonged.

\section{SUMMARY}

1. Studies on 44 patients suffering from heat stroke are presented.

2. Cardiac failure or peripheral circulatory collapse was not evident in the majority of patients.

3. The sodium chloride content of the blood was not significantly altered.
4. The condition was associated with a moderate acidosis and hemoconcentration.

5. The high body temperature appeared to be the chief cause of the symptoms of heat stroke.

6. Old age, degenerative disease, and acute alcoholism are important contributing factors in heat stroke.

7. The onset was precipitated by a diminution or cessation of sweat in the majority of patients.

8. Although the primary cause for the sudden cessation of sweat has not been determined, it would appear from these studies that loss of chlorides, dehydration, and circulatory failure were not responsible.

9. Measures to lower the body temperature promptly are indicated; in our hands ice water tubbing with massage was the most effective method in severe cases.

\section{BIBLIOGRAPHY}

1. Edsall, David L., A disorder due to exposure to intense heat, characterized clinically chiefly by violent muscular spasms and excessive irritability of the muscles. Preliminary note. J. A. M. A., 1908, 51, 1969.

2. Moss, K. N., Some effects of high air temperatures and muscular exertion upon colliers. Proc. Roy. Soc. London, B, 1923-24, 95, 191.

3. Haldane, J. S., Salt depletion by sweating. Brit. M. J., 1929, 2, 469

4. Glover, Donald M., Heat cramps in industry. Their treatment and prevention by means of sodium chloride. J. Indust. Hyg. and Toxicol., 1931, 13, 347.

5. Talbott, J. H., and Michelsen, J., Heat cramps. A clinical and chemical study. J. Clin. Invest., 1933, 12, 533.

6. Talbott, J. H., Dill, D. B., Edwards, H. T., Stumme, E. H., and Consalzio, W. V., The ill effects of heat upon workmen. J. Indust. Hyg. and Toxicol., 1937, 19, 258.

7. Derrick, E. H., Heat cramps and uremic cramps with special reference to their treatment with sodium chloride. M. J. Australia, 1934, 2, 612.

8. Gauss, H., and Meyer, K. A., Heat stroke: report of 158 cases from Cook County Hospital, Chicago. Am. J. M. Sc., 1917, 154, 554.

9. Wilcox, W. H., The nature, prevention and treatment of heat hyperpyrexia. The clinical aspect. Brit. M. J., 1920, 1, 392.

10. Sayers, R. R., and Davenport, S. J., Review of literature on the physiological effects of abnormal temperatures and humidities.' Pub. Health Rep., 1927, 42, 933.

11. Adolph, Edward F., and Fulton, W. B., The effects of exposure to high temperatures upon the circulation in man. Am. J. Physiol. 1923-24, 67, 573. 
12. Morton, T. C. St. C., The aetiology and treatment of heat exhaustion and heat hyperpyrexia, with special reference to experiences in Iraq. Proc. Roy. Soc. Med., 1932, 25, 1261.

13. Sturgis, C. C., The effects of heat. Oxford Med., Oxford University Press, N. Y., 1926, 4, 664.

14. Wakefield, E. G., Heat injuries. Proc. Staff Meet., Mayo Clin., 1936, 11, 483.

15. Drinker, C. K., The effects of heat and humidity upon the human body. J. Indust. Hyg. and Toxicol., 1936, 18, 471.

16. Metropolitan Life Insurance Company, Death from heat and sunstroke in the United States. Statistical Bulletin, July 1936, 17, Number 7.

17. Talbott, J. H., Edwards, H. T., Dill, D. B., and Drastich, L., Physiological responses to high environmental temperature. Am. J. Trop. Med., $1933,13,381$.

18. Allen, G. P. F., Heat cramp and heat hyperpyrexia. Brit. M. J. (Notes), 1928, 1, 1098.

19. Van Zwalenburg, C., Heat prostration and dehydration. (Correspondence) J. A. M. A., 1933, 101, 1253.

20. Barr, David P., In Musser, J. H., Internal Medicine. Lea and Febiger, Philadelphia, 1934, 2d ed., p. 1027.

21. Hearne, K. G., Hyperpyrexial heat stroke: a brief note on its etiology and prevention. Brit. M. J., 1919, 1, 516.

22. McCrae, Thomas, Osler's Principles and Practise of Medicine. Appleton-Century, New York, 1935, 12th ed., p. 361.

23. Duncan, A., Remarks on some recent theories on the action of heat in the tropics. J. Roy. Army M. Corps, 1908, 11, 71.

24. Fantus, B., Therapy of disturbances due to heat. J. A. M. A., 1934, 103, 990.

25. Moritz, F., and v. Tabora, D., Uber eine Methode, beim Menschen den Druck in oberflächlichen Venen exakt zu bestimmen. Deutsches Arch. f. klin. Med., 1910, 98, 475.

26. Van Slyke, D. D., The determination of chlorides in blood and tissues. J. Biol. Chem., 1923, 58, 523.

27. Austin, J. H., Cullen, G. E., Hastings, A. B., McLean, F. C., Peters, J. P., and Van Slyke, D. D., Studies of gas and electrolyte equilibria in blood. I. Technique for collection and analysis of blood, and for its saturation with gas mixtures of known composition. J. Biol. Chem., 1922, 54, 121.

28. Peters, J. P., and Van Slyke, D. D., Quantitative Clinical Chemistry. Vol. II. Methods. Williams and Wilkins Co., Baltimore, 1932.

29. Palmer, W. W., The colorimetric determination of hemoglobin J. Biol. Chem., 1918, 33, 119.

30. Guest, G. M., and Siler, Vinton E., A centrifuge method for the determination of the volume of cells in blood. J. Lab. and Clin. Med., 1934, 19, 757.

31. Howe, P. E., The determination of proteins in blood, a micro-method. J. Biol. Chem., 1921, 49, 109.

32. Robinson, H. W., Price, J. W., and Cullen, G. E., Studies on the acid-base condition of blood. V. The influence of protein concentration on the colorimetric $\mathrm{pH}$ determination of blood serum. J. Biol. Chem., 1936, 114, 321.

33. Butler, A. M., and Tuthill, E., An application of the uranyl zinc acetate method for determination of sodium in biological material. J. Biol. Chem., 1931, 93, 171.

34. Shohl, A. T., and Bennett, H. B., A micro-method for the determination of potassium as iodoplatinate. J. Biol. Chem., 1928, 78, 643.

35. Austin, J. H., and Cullen, G. E., Hydrogen ion concentration of the blood in health and disease. Medicine, 1925, 4, 275.

36. Hall, W. W., and Wakefield, E. G., A study of experimental heat-stroke. J. A. M. A., 1927, 89, 177.

37. Saffert, C. A., Heat hyperpyrexia; report of extreme case surviving for $8 \frac{1}{2}$ days. Minnesota Med., 1937, 20, 106.

38. McKenzie, Pierce, and LeCount, E. R., Heat stroke with a second study of cerebral edema. J. A. M. A., 1918, 71, 260.

39. Cameron, W. H., A disorder due to exposure to intense heat. J. A. M. A., 1909, 52, 1483.

40. Phelps, J. R., Heat cramps and heat exhaustion on board ships of the navy in recent months. U. S. Nav. M. Bull., 1926, 24, 145.

41. Steele, J. M., Elevation of rectal temperature following mechanical obstruction to the peripheral circulation. Am. Heart J., 1937, 13, 542.

42. Porter, W. T., and Turner, A. H., Further evidence of a vasotonic and a vasoreflex mechanism. Am. J. Physiol., 1915-16, 39, 236.

43. McDowall, R. J. S., The action of alcohol on the circulation. J. Pharmacol. and Exper. Therap., 1925, 25, 289.

44. Stewart, G. N., Studies on the circulation in man. XV. Further observations, chiefly pharmacological, on the criteria by which deficiencies in the bloodflow (in the hands or feet) due to mechanical causes may be discriminated from changes due to functional (vasomotor) causes. J. Pharmacol. and Exper. Therap., 1915, 7, 281.

45. Barbour, H. G., and Bourne, W., Heat regulation and water exchange. IV. The influence of ether in dogs. Am. J. Physiol., 1923-24, 67, 399.

46. Kuno, Y., The Physiology of Human Perspiration. J. and A. Churchill, London, 1934.

47. Heilman, M. W., and Montgomery, E. S., Heat disease: a clinical and laboratory study. J. Indust. Hyg. and Toxicol., 1936, 18, 651. 